\title{
Correction to: Interventions Addressing Depression and HIV-Related Outcomes in People with HIV
}

\author{
Noelle A. Mendez ${ }^{1}\left(\mathbb{D} \cdot\right.$ Daniel Mayo $^{1}\left(\mathbb{1} \cdot\right.$ Steven A. Safren $^{1}(\mathbb{C}$
}

Published online: 27 October 2021

๑) Springer Science+Business Media, LLC, part of Springer Nature 2021

Correction to: Current HIV/AIDS Reports (2021) 18:377-390

https://doi.org/10.1007/s11904-021-00559-w

The originally published article did not include 5R01MH103770 awarded to Dr. Steven Safren and Conall O'Cleirigh, which also supported author time.

Publisher's Note Springer Nature remains neutral with regard to jurisdictional claims in published maps and institutional affiliations.

The original article can be found online at https://doi.org/10.1007/ s11904-021-00559-w.

Steven A. Safren ssafren@miami.edu

Noelle A. Mendez nmendez2@miami.edu

Daniel Mayo

dmayo@miami.edu

1 Department of Psychology, University of Miami,

Coral Gables, FL, USA 